\title{
Article
}

\section{Combustion Performance and Low NOx Emissions of a Dimethyl Ether Compression-Ignition Engine at High Injection Pressure and High Exhaust Gas Recirculation Rate}

\author{
Inmo Youn ${ }^{1}$ and Joonho Jeon ${ }^{2, *}$ D \\ 1 Korean Institute of Energy Technology Evaluation and Planning, 14 Teheran-ro 114 Gil, Gangnam-gu, \\ Seoul 06175, Korea; youninmo@naver.com \\ 2 Department of Fire Protection Engineering, Pukyong National University, 45 Yongso-ro, Nam-gu, \\ Busan 48513, Korea \\ * Correspondence: jeonj@pknu.ac.kr; Tel.: +82-51-629-6490
}

Citation: Youn, I.; Jeon, J. Combustion Performance and Low NOx Emissions of a Dimethyl Ether Compression-Ignition Engine at High Injection Pressure and High Exhaust Gas Recirculation Rate. Energies 2022, 15, 1912. https://doi.org/10.3390/ en15051912

Academic Editor: Attilio Converti

Received: 14 February 2022

Accepted: 2 March 2022

Published: 5 March 2022

Publisher's Note: MDPI stays neutral with regard to jurisdictional claims in published maps and institutional affiliations.

Copyright: () 2022 by the authors Licensee MDPI, Basel, Switzerland. This article is an open access article distributed under the terms and conditions of the Creative Commons Attribution (CC BY) license (https:// creativecommons.org/licenses/by/ $4.0 /)$.

\begin{abstract}
Dimethyl ether (DME) is a promising alternative to diesel for compression-ignition (CI) engines used in various industrial applications. However, the high nitrogen oxide (NOx) emissions of DME combustion have restricted its use. The primary cause of high NOx emissions is a high combustion temperature. In this study, a high exhaust gas recirculation (EGR) rate was used when testing a common-rail direct injection $\mathrm{CI}$ engine suitable (with minor modifications) for a passenger car. A modified fuel supply system created high injection pressure during evaluation of combustion performance. The physical and chemical properties of DME were the principal determinants of the ignition delay, combustion speed, and heat release rate. Although a high injection pressure accelerated formation of the fuel-air mixture and the combustion speed, combustion performance deteriorated with increased NOx emissions. An increased EGR rate affected combustion and the NOx concentration. A high EGR rate effectively reduced NOx formation and emission under lowtemperature combustion conditions. Also, the good DME combustion characteristics were maintained when the EGR rate was high, unlike for an ultra-low sulfur diesel engine.
\end{abstract}

Keywords: dimethyl ether; exhaust gas recirculation; nitrogen oxides; combustion process

\section{Introduction}

Clean energy has become a major issue, especially for of internal combustion (IC) engines. Although alternatives to IC engines powered by fossil fuels include electric energy, fuel cells, and engines that use renewable energy, many existing industrial IC engines will continue to be used for some time. Stringent emission regulations and high efficiency requirement are driving the development of IC engines via advanced combustion techniques, aftertreatment systems and mechanical engine techniques [1,2]. Compression ignition (CI) engines are widely for transportation, construction, and agriculture, and in marine industries, due to their high combustion efficiency, and good fuel economy and output power. The strict emissions regulations applicable to $\mathrm{CI}$ engines used for transportation will soon apply to all such engines. Thus, an alternative combustion technology is necessary.

Dimethyl ether (DME), as an organic fuel $\left(\mathrm{CH}_{3} \mathrm{OCH}_{3}\right)$, is a good alternative to diesel fuel. DME can be produced from multiple sources via either direct or indirect synthesis. DME can be obtained directly from natural gas, and synthesized indirectly from methanol. DME exhibits useful thermal and chemical properties, and can be used as a substitute for diesel in CI engines. Many studies on DME combustion and emissions have been conducted to design engine system fueled by DME could substitute for diesel engines.

Various injection strategies [3-8], engine operation conditions [9-11] and fuel blends [12-18] of DME-fueled engines have been investigated. Youn et al. [8] showed that the use of DME was associated with a higher pressure and earlier increase in the 
heat release rate (HRR) compared to diesel, because the ignition delay was shorter, the vaporization characteristics were more favorable, and the cetane number was higher. Jeon et al. $[7,11]$ studied DME combustion and fuel/air mixture formation process using experimental and numerical methods. As no diffusion flames appeared during DME combustion, the numerical results showed that the combustion temperature of DME was higher than that of diesel. They used a pilot injection strategy that reduced the combustion temperature. Mehra and Agarwal [6] reported reduced exhaust emissions from a DME engine, with low-temperature combustion, using multiple injection strategies. This enabled reductions in nitrogen oxide $\left(\mathrm{NO}_{\mathrm{x}}\right)$ and soot emissions when the combustion temperature is decreased during the combustion process. As the physical properties of DME are similar to those of liquefied petroleum gas (LPG), DME has been blended successfully with diesel [12], LPG [13], biodiesel [16,17], gasoline [18] and other fuels [14,15].

DME would be a valuable alternative to diesel, but the high engine-out $\mathrm{NO}_{\mathrm{x}}$ emissions remain problematic [19-21]. The high DME flame temperature elevates $\mathrm{NO}_{\mathrm{x}}$ concentrations. Advanced combustion strategies and aftertreatment systems have been studied in an effort to reduce $\mathrm{NO}_{\mathrm{x}}$ emissions. Multiple injection strategies and exhaust gas recirculation (EGR) effectively reduced the combustion temperature. A lean $\mathrm{NO}_{\mathrm{x}}$ trap and selective catalyst reduction (aftertreatment systems) have been used to decompose $\mathrm{NO}_{\mathrm{x}}$ emissions before the tailpipe. However, this increases costs, and the complexity of control; moreover, the backpressure compromises engine performance. An in-cylinder combustion regime with low $\mathrm{NO}_{x}$ production/emission would increase the applicability of DME.

This work aimed to reduce $\mathrm{NO}_{\mathrm{x}}$ emissions from the DME engine of a passenger car using a high injection pressure and high EGR rate. Given the high compressibility and low lubrication of DME, it was challenging to design an injection system that supplied sufficient fuel at a stable injection pressure. Previous studies used mechanical injection pumps or low injection pressures (<50 MPa). In this work, a common-rail direct injection diesel engine with an electronic control system was used for a passenger car after minor modifications. In summary, the present investigated how DME can fuel high-performance $\mathrm{CI}$ engines, with lower $\mathrm{NO}_{\mathrm{x}}$ and toxin emissions compared to a diesel engine.

\section{Experimental}

\subsection{Fuel Properties}

DME and ultra-low sulfur diesel (ULSD) were used to investigate the effects of injection pressure and the EGR rate on the combustion and emission characteristics of a CI engine. DME is a good alternative to diesel, exhibiting excellent auto-ignition and evaporation properties. The low boiling temperature and vapor pressure of DME improve fuel atomization and air mixing when forming a homogeneous fuel-air mixture. In terms of its chemical properties, DME contains $34.7 \mathrm{wt} \%$ oxygen, which serves as an oxidizer during combustion. Unlike ULSD, DME lacks carbon-to-carbon $(\mathrm{C}-\mathrm{C})$ bonds, which significantly reduces soot formation. The physical and chemical properties of the fuels are listed in Table 1. The fuel properties were collected from Refs [22-29].

Table 1. Physical and chemical properties of test fuels [22-29].

\begin{tabular}{ccc}
\hline Properties & ULSD & DME \\
\hline Chemical formula & $\mathrm{C}_{8}$ to $\mathrm{C}_{25}$ & $\mathrm{CH}_{3} \mathrm{OCH}_{3}$ \\
Cetane number $[22,23]$ & $40 \sim 55$ & $55 \sim 60$ \\
Oxygen contents $(\mathrm{wt} \%)$ & - & 34.7 \\
Lower heating value $(\mathrm{MJ} / \mathrm{kg})[24]$ & 42.50 & 28.43 \\
Boiling temperature $\left({ }^{\circ} \mathrm{C}\right)[25]$ & $150 \sim 380$ & -25 \\
Liquid density $\left(\mathrm{kg} / \mathrm{m}^{3}\right.$ at $\left.20^{\circ} \mathrm{C}\right)$ & $800 \sim 840$ & 670 \\
Liquid viscosity $\left(\mathrm{kg} / \mathrm{m} \cdot \mathrm{s}\right.$ at $\left.25^{\circ} \mathrm{C}\right)[26,27]$ & $2 \sim 4$ & $0.12 \sim 0.15$ \\
Vapor pressure $\left(\mathrm{MPa}\right.$ at $\left.25^{\circ} \mathrm{C}\right)[28]$ & $<0.001$ & 0.51 \\
Latent heat of vaporization $(\mathrm{kJ} / \mathrm{kg})[29]$ & 250 & 460
\end{tabular}




\subsection{Engine System}

A four-cylinder compression-ignition (CI) engine designed for a passenger car was used in all experiments. Table 2 shows the specifications of the $1.6 \mathrm{~L}$, variable geometric turbo engine with direct-injection solenoid injectors. A Bosch engine control unit (EDC16 ETK) and ETAS INCA software (ver. 5.4) were used for controlling all engine parameters. The engine was coupled to a Froude eddy current dynamometer (AG150) that controlled engine speed and torque. High-speed engine pressure data were collected and averaged using a Kistler pressure sensor (6057ASP) and a National Instruments data acquisition system. LabVIEW real-time software sampled high-speed data over 100 cycles, and estimated the main combustion parameters (HRR, indicated mean effective pressure [IMEP], and brake mean effective pressure [BMEP]).

Table 2. Test engine geometry and specifications.

\begin{tabular}{cc}
\hline Description & Specification \\
\hline Engine type & 4-stroke VGT DI diesel engine \\
Number of cylinders & 4 \\
Bore $\times$ Stroke $(\mathrm{mm})$ & $77.2 \times 84.5$ \\
Displacement $(\mathrm{L})$ & 1.582 \\
Compression ratio & $17.3: 1$ \\
Intake valve open/close & BTDC $6^{\circ} / \mathrm{ABDC}_{3}^{\circ}$ \\
Exhaust valve open/close & BBDC $46^{\circ} / \mathrm{ATDC}^{\circ}$ \\
Max Rail Pressure (MPa) & 160 \\
\hline
\end{tabular}

Figure 1 shows a schematic of the engine and exhaust sampling system. Gaseous emissions were measured using a portable emissions analyzer (MEXA-554JKNO $\mathrm{K}_{\mathrm{x}}$; Horiba (Anyang, Korea)) with a non-dispersive infrared (NDIR) sensor and an electrochemical skin conductance (ESC) sensor. Particulate matter (PM) emissions were measured using an AVL smoke meter (415S). The emissions under each engine condition were averaged over a 3-min period after a 10-min stabilization period.

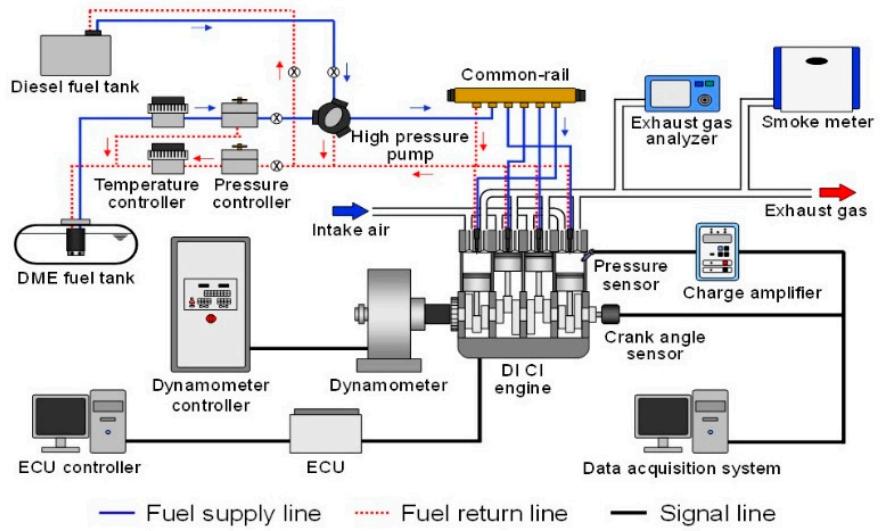

Figure 1. Engine and sampling system schematic showing instruments used in the experimental study.

\subsection{Experimental Procedure}

The engine was operated at a constant speed and torque (1500 rpm and $50 \mathrm{~N} \cdot \mathrm{m})$. The injection pressure and EGR rate were varied. The injection pressure was increased from 30 to $70 \mathrm{MPa}$ in increments of $10 \mathrm{MPa}$. The EGR rate was controlled by an EGR valve from 10 to $50 \%$ (in 10\% increments). A higher EGR rate increased the ignition delay, which was compensated for using single pilot injection. The injection timing and pilot quantity were before top dead center (BTDC) $30^{\circ}$ and $1.6 \mathrm{mg}$ per cycle, respectively, under EGR conditions. In each test, the injection pressure and EGR rate that best maintained the engine speed and torque were defined. However, the main injection timing was fixed at the top dead center (TDC). Given the low liquid viscosity of DME, the injection system can be easily damaged 
during fuel supply and return. Thus, a lubrication additive (539M; Lubrizol (Wickliffe, OH, USA)) was blended with DME at $1 \% v / v$.

\section{Results and Discussion}

The combustion performance and emission characteristics of DME and ULSD fuels in different injection pressure and EGR rate conditions were investigated by experimental approach. The experimental results show the combustion features of DME fuel in terms of in-cylinder pressure, ignition delay, combustion duration and thermal efficiency as compared with ULSD fuel. In addition, the gaseous and solid emissions were analyzed under various injection pressure and EGR rate conditions.

\subsection{Injection Pressure}

Figure 2 compares the combustion characteristics of DME and ULSD with single injections (30 MPa injection pressure) at TDC. The HRR curves were calculated based on the measured in-cylinder pressure. The ignition delay is defined as the difference between the time at which a 10\% HRR was achieved and the start of the first injection. Given its higher cetane number, DME combustion initiated earlier than that of ULSD. In addition, DME formed a combustible fuel/air mixture within a short time because of its high evaporation rate and low boiling temperature. Thus, the ignition delay was short and premixed combustion was strong, as reflected in the HRR curves. DME combustion exhibited the conventional HRR profile of a CI engine, i.e., included both premixed and diffusion combustion phases. Although the ignition timing was as short as 13.5 CAD, the total combustion duration was longer than that of ULSD due to the long diffusion combustion time. Under the same engine conditions, diesel exhibited a long premixed combustion phase, longer ignition delay prior to the formation of a homogeneous fuel/air mixture, and shorter total combustion time. The higher heating value of ULSD provided higher power (to meet the engine load), and the maximum pressure occurred during the late expansion stroke.

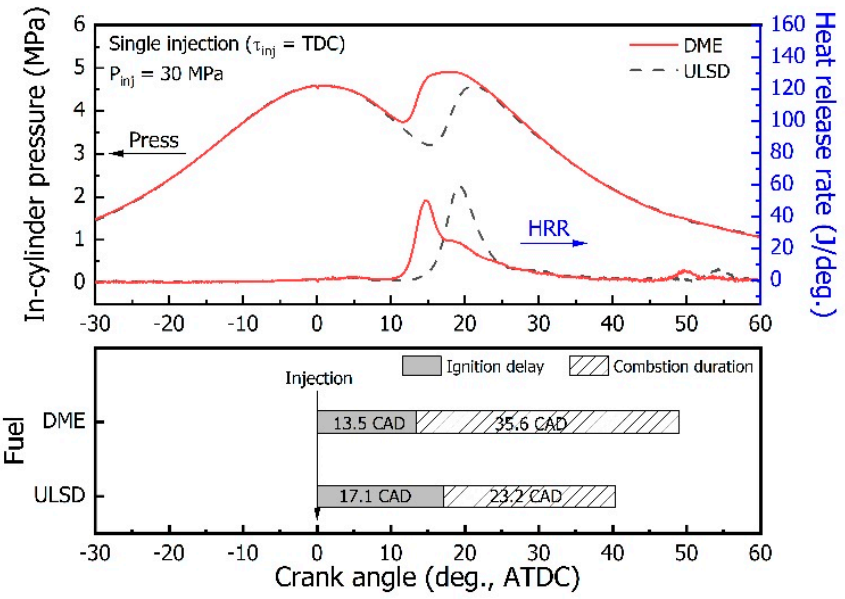

Figure 2. Combustion characteristics of in-cylinder pressure, heat release rate (up) and ignition delay, combustion duration (down) for DME and ULSD fuels.

Figure 3 shows the in-cylinder pressure and HRR of DME at three injection pressures. The ignition delay is known to be shorten at higher injection pressures. The injection pressure determines the spray breakup and mixture characteristics in the combustion chamber; higher pressure yields smaller fuel droplets, which evaporate quickly. The effect of injection pressure on ignition delay was largest at $40 \mathrm{MPa}$. The difference in ignition delay between 30 and $40 \mathrm{MPa}$ was the largest among all differences evaluated, perhaps reflecting effects on spray atomization. Similar trends have been reported in other spray tests. Yu and Bae showed that the DME spray penetration length varied by injection 
pressure [30]. The penetration length increased markedly up to an injection pressure of $40 \mathrm{MPa}$, but increased much more gradually thereafter.

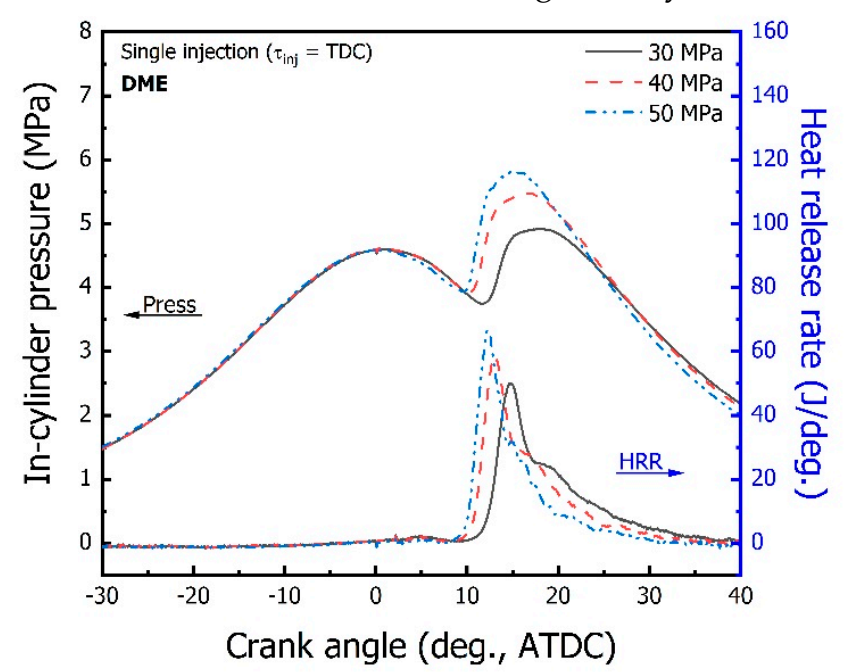

Figure 3. In-cylinder pressure and heat release rate traces for DME fuel under three injection pressure conditions.

The reduction in fuel drop diameter as the injection pressure increased resulted in a higher combustion pressure and HRR. The fuel drops mixed rapidly with air, forming combustible mixtures; they also burned quickly, resulting in a marked pressure rise. The HRR curves indicate strong premixed combustion with reductions in secondary peaks; this increased $\mathrm{NO}_{\mathrm{x}}$ emissions, as described below. Although various injection pressures were associated with different spray and combustion characteristics, fuel consumption remained similar at the same engine load (Figure 4).

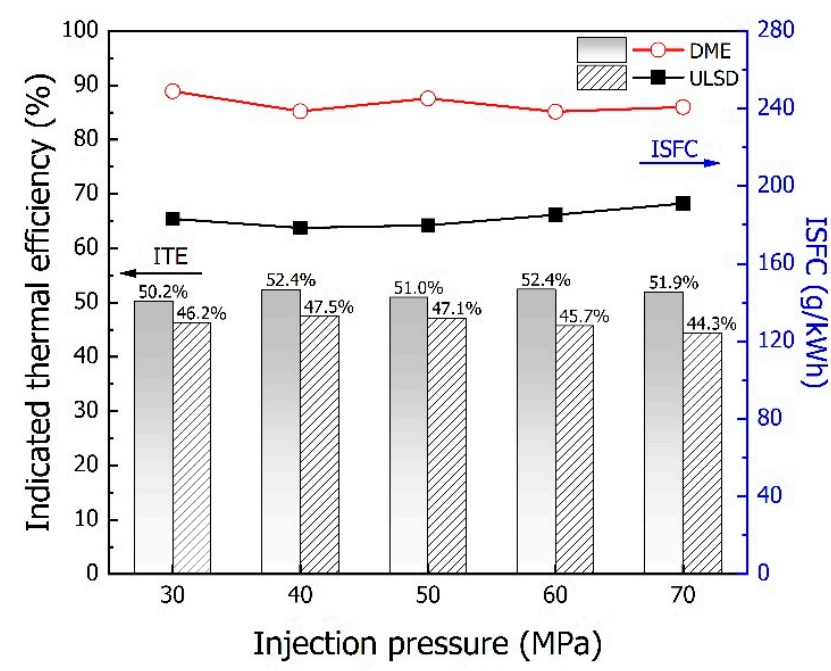

Figure 4. Indicated thermal efficiency and indicated specific fuel consumption for DME and ULSD fuels as a function of injection pressure.

Figure 4 shows the indicated thermal efficiency (ITE) and indicated specific fuel consumption (ISFC) for each test fuel at five injection pressures. The ITE was calculated as the ratio of burnt fuel energy to input fuel energy on a lower heating value (LHV) basis. The short ignition delay and fast combustion of DME increased the fuel conversion rate during combustion compared to that of ULSD, and reduced heat loss under the relatively higher ambient pressure/temperature conditions present at the start of combustion. Given the lower LHV of DME, $48 \%$ more DME than ULSD was required to produce the same energy in the combustion chamber [31]. In this study, 26-36\% more DME fuel mass was 
consumed compared to ULSD. As mentioned previously, the effect of injection pressure on fuel consumption was negligible, perhaps because the injection timing was late and the engine load high. However, this hypothesis requires validation.

The injection pressure affected the concentrations of gaseous and solid emissions at the same engine load. Figure 5 shows the $\mathrm{NO}_{\mathrm{x}}$, soot, carbon monoxide (CO), and hydrocarbon (HC) levels on an indicated power basis for DME and ULSD. The short ignition duration of DME-air mixtures is known to produce higher $\mathrm{NO}_{\mathrm{x}}$ emissions at high combustion temperatures [21]. An increased injection pressure reduced the time required to form a combustible mixture, resulting in higher combustion temperatures and $\mathrm{NO}_{\mathrm{x}}$ concentrations for both fuels. In contrast, the soot concentration was decreased as the injection pressure increased, and the mixture became less fuel-rich. ULSD exhibited the lowest soot concentration at an injection pressure of $70 \mathrm{MPa}$. As DME lacks carbon-tocarbon bonds and had an oxygen content of 35\%, DME soot concentrations were near-zero regardless of the injection pressure. The $\mathrm{HC}$ and $\mathrm{CO}$ emissions of the DME-fueled engine were consistently lower than those of the ULSD-fueled engine. DME has high combustion efficiency, good spraying physics, and good chemical combustion (incomplete combustion is suppressed) [31,32]. The high CO and HC emissions of ULSD at high injection pressures may be caused by incomplete combustion on the cylinder wall. The longer spray tip penetration at high injection pressure might lead to fuel film formation on the wall; this may explain the high $\mathrm{CO}$ and $\mathrm{HC}$ emissions.
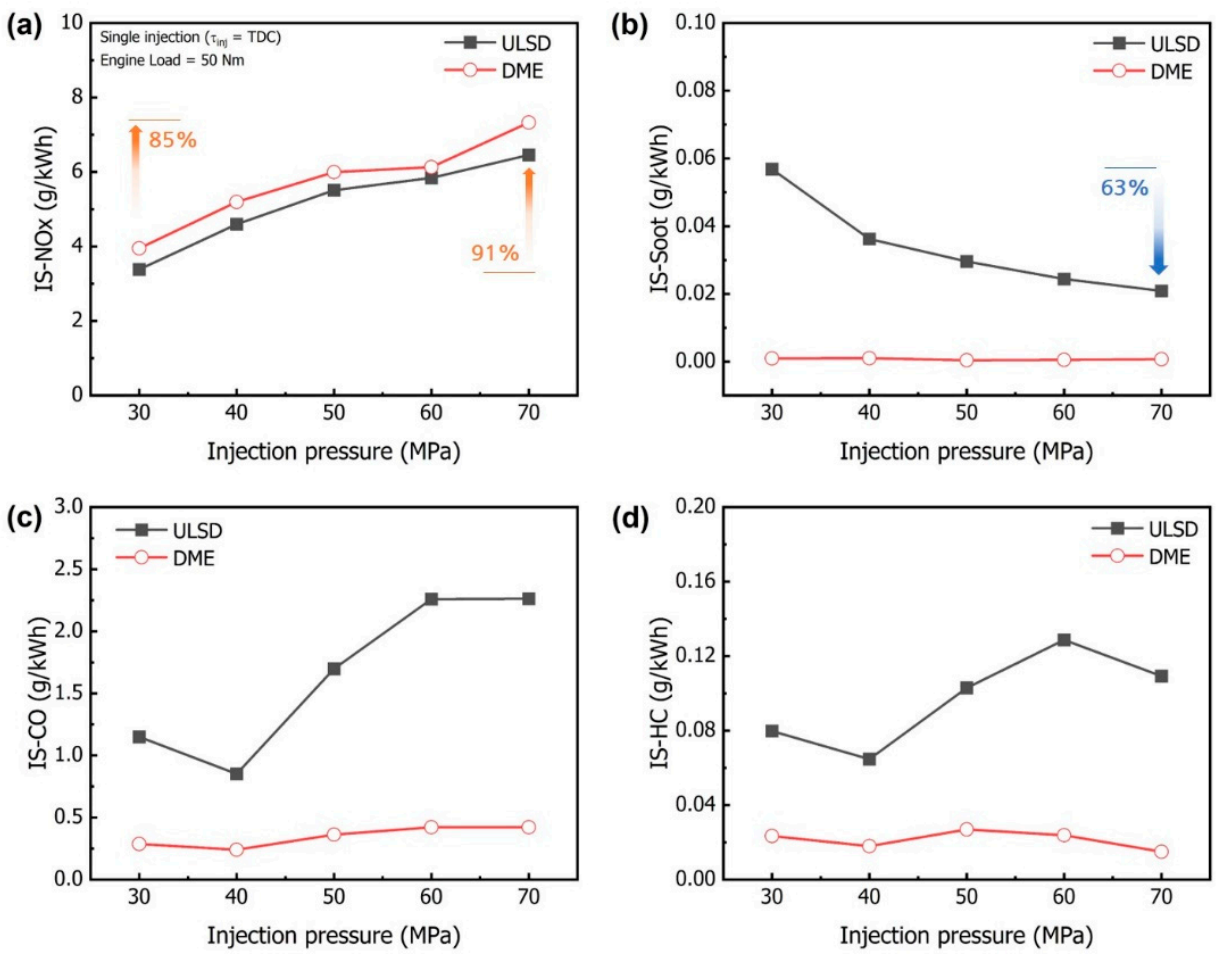

Figure 5. Engine-out emissions;(a) nitrogen oxides, (b) soot, (c) carbon monoxide and (d) unburned hydrocarbon for DME and ULSD fuels as a function of injection pressure.

\subsection{Exhaust Gas Recirculation (EGR)}

In this study, the EGR rate was varied from $10 \%$ to a high rate of $50 \%$, in increments of $10 \%$, to explore combustion and emission characteristics. Combustion of each fuel was compared based on the in-cylinder average pressure and HRR at the high EGR (50\%), with pilot injection (Figure 6). Rapid formation of a DME fuel-air mixture enabled earlier combustion than that of ULSD. The ignition ULSD was greatly delayed by EGR, which decreased the ambient temperature, but the effect of EGR on DME ignition was small. The HRR curve shows that the combustion phase clearly differed between the two fuels. The relatively homogeneous charge and short ignition delay of the DME mixture generated high 
heat energy within a short period of combustion, indicating high combustion efficiency. Heat loss was reduced compared to that during ULSD combustion.

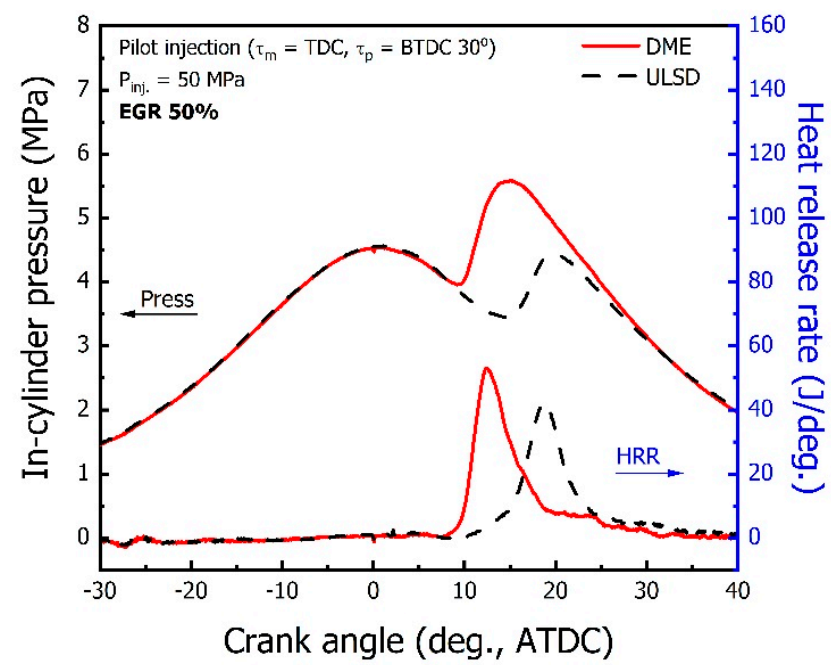

Figure 6. In-cylinder pressure and heat release rate traces for DME and ULSD fuels at EGR 50\% rate.

Figure 7 compares the accumulated HRR curves for DME and ULSD at an EGR rate of $50 \%$. The cumulative HRR varied by the combustion characteristics in the ignition and combustion phases. The short ignition delay of DME was associated with early energy release and fast burning; these factors led to a sharp increase in the slope. As mentioned above, the homogeneous mixture induced strongly premixed combustion that produced a large amount of energy over a short period of time [33]. DME combustion was associated with a higher rate of energy release than USLD combustion, attributable to fast evaporation and the high oxygen content of DME. These factors affected the ITE results, as shown in Figure 8.

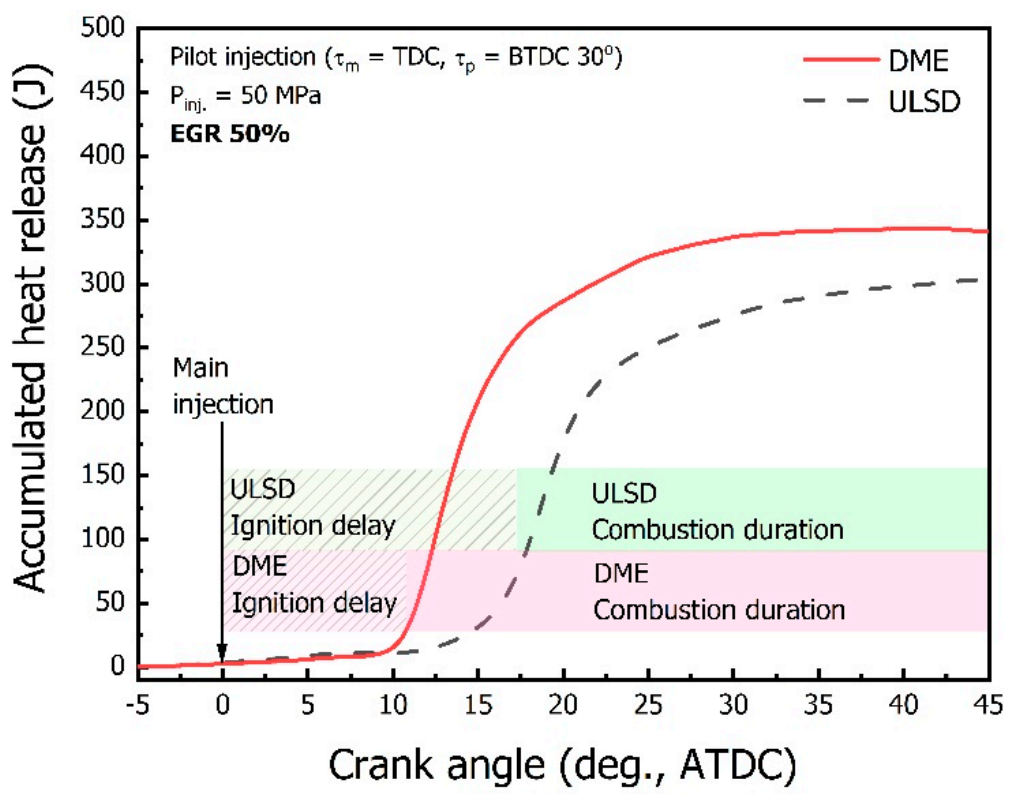

Figure 7. Accumulated heat release for DME and ULSD fuels at 50\% EGR conditions.

EGR is known to reduce the temperature of burnt gas in the cylinder because the specific heat is high. Thus, EGR is used to suppress $\mathrm{NO}_{\mathrm{x}}$ formation/emission during combustion. It has been suggested that DME engines produce more $\mathrm{NO}_{\mathrm{x}}$ than diesel engines. Figure 8 compares the ITE and ISFC between the two fuels as the EGR rate varied. A higher EGR rate reduced thermal efficiency and fuel consumption. A low combustion 
temperature slows fuel droplet evaporation and flame propagation. The USLD combustion performance decreased as the EGR rate increased, but DME combustion was barely affected ( $2 \%$ reduction of thermal efficiency and $4 \%$ increase in fuel consumption between the EGR rates of 0 and $50 \%$ ). This is attributable to the high evaporation rate and oxygen content of DME, which together induce fast and relatively complete combustion at high EGR rates. Thus, DME engines with a high EGR rate show lower NOx emissions with no loss of combustion performance.

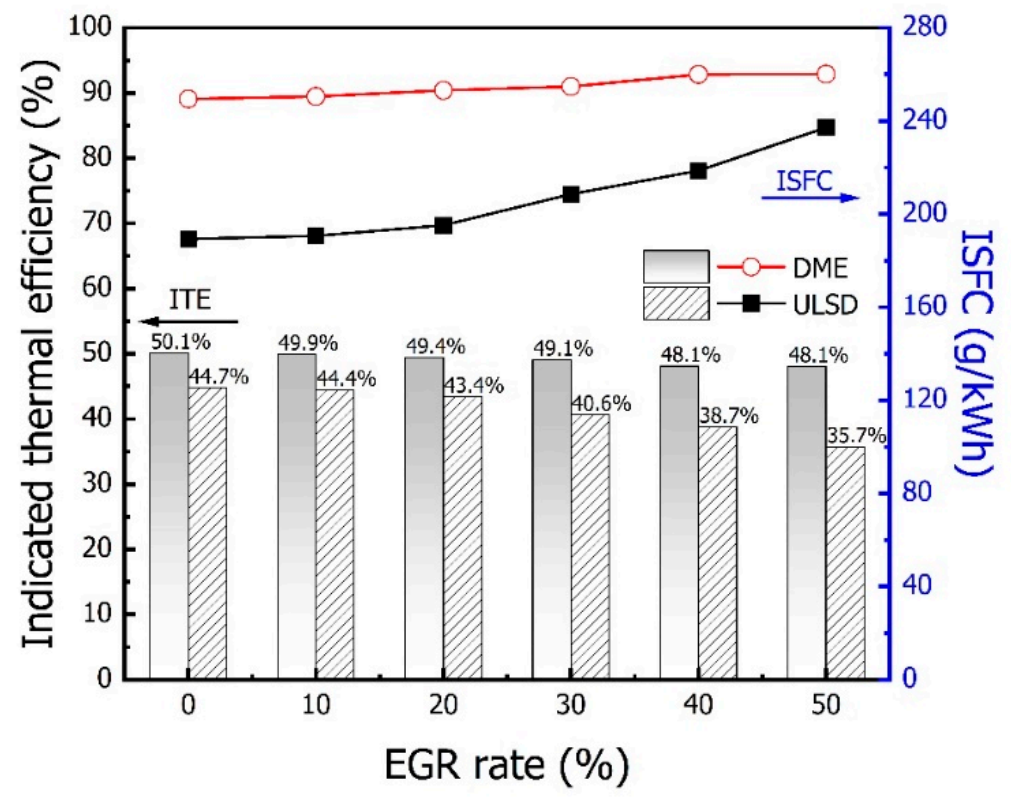

Figure 8. Indicated thermal efficiency and indicated specific fuel consumption for DME and USLD fuels as a function of EGR rate.

Figure 9 shows the engine-out gaseous and soot emissions as a function of the EGR rate for DME and ULSD. The low combustion temperature during EGR suppressed $\mathrm{NO}_{\mathrm{x}}$ formation; it is known that $\mathrm{NO}_{\mathrm{x}}$ concentrations are strongly affected by combustion temperature. The highest EGR rate (50\%) dramatically reduced $\mathrm{NO}_{\mathrm{x}}$ emissions, by $73 \%$ and $80 \%$ for DME and ULSD, respectively. An increased EGR rate induced incomplete combustion of ULSD, associated with lower $\mathrm{NO}_{x}$ concentrations at all EGR rates compared to those of DME. The $\mathrm{CO}$ and unburnt HC levels increased at higher EGR rates because combustion was less complete. We also observed the typical $\mathrm{NO}_{\mathrm{x}}$-soot trade-off relationship for ULSD. As mentioned above, DME combustion is associated with near-zero soot emissions; there are no carbon-to-carbon bonds and the oxygen content is high. Note that a high EGR during DME combustion effectively suppresses the formation of $\mathrm{NO}_{\mathrm{x}}$, because the combustion temperature falls, while soot emissions remain near zero and good combustion performance is maintained. 

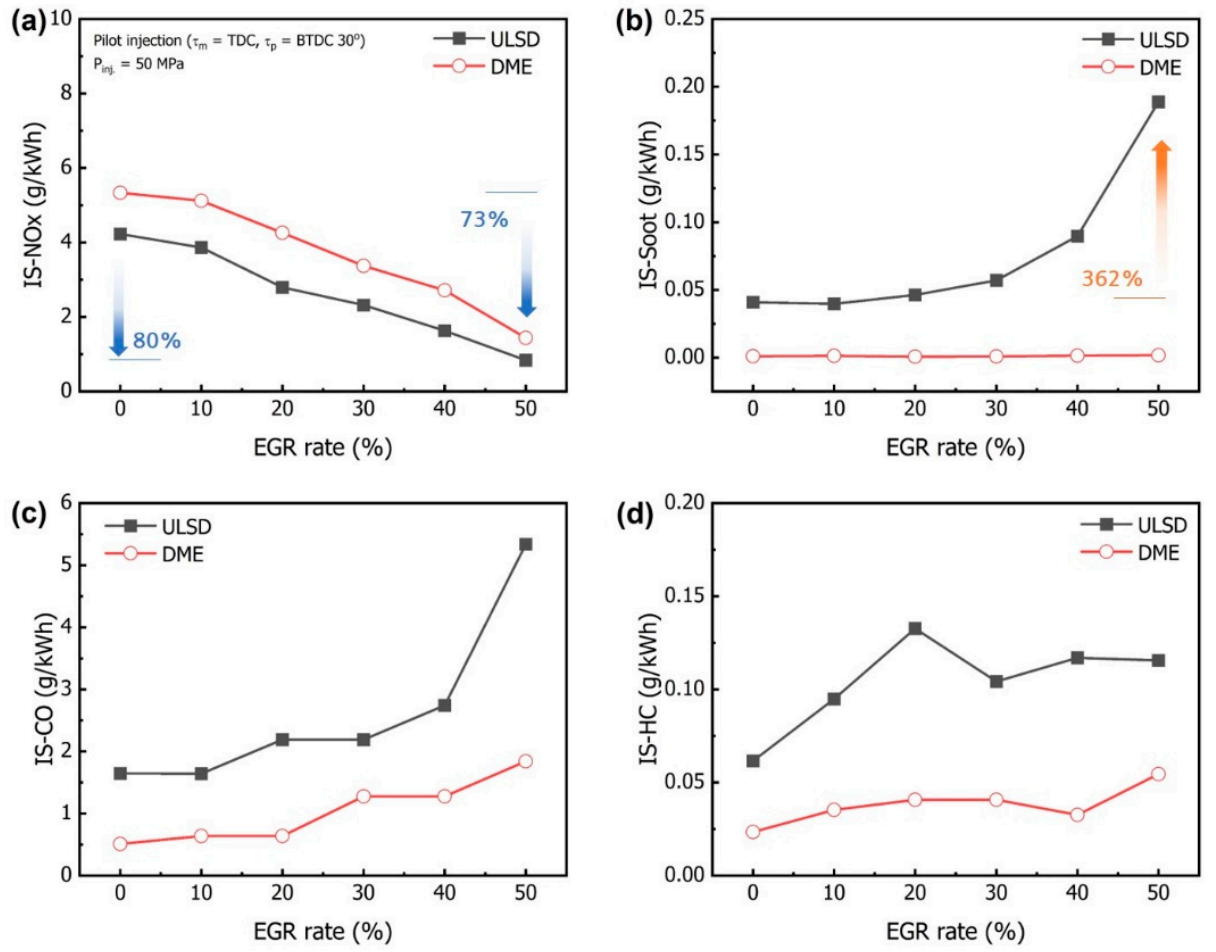

Figure 9. Engine-out emissions; (a) nitrogen oxides, (b) soot, (c) carbon monoxide and (d) hydrocarbon for DME and ULSD fuels as a function of EGR rate.

\section{Conclusions}

We varied the injection pressure and EGR rate when studying the combustion and emission characteristics of engines burning DME and ULSD. We aimed to greatly reduce $\mathrm{NO}_{\mathrm{x}}$ emissions in the combustion chamber using a high injection pressure and high EGR rate. The results showed that DME engines may meet stringent emissions regulations, and could replace ULSD engines. Our principal findings are as follows:

(1) The physical and chemical properties of DME (high cetane number, oxygen content, and evaporation rate) are the principal determinants of the combustion characteristics. The short ignition delay and fast combustion speed of DME ensure combustion efficiency regardless of the operation conditions, injection pressure, or EGR rate. At a high EGR rate, DME combustion efficiency is reduced slightly to $2 \%$, and a high injection pressure does not improve DME combustion.

(2) Increased injection pressure induces higher combustion temperature and lower combustion efficiency of DME and ULSD. Thus, NOx emissions are increased up to $91 \%$ at high injection pressures for DME fuel. However, for DME engines, a high injection pressure is not necessary to achieve high combustion efficiency or reduce emissions. A lower injection pressure provides both high performance and low engine-out emissions.

(3) A high EGR rate when using DME ensures low levels of combustion-produced NOx emissions with a reduction of $73 \%$ in the combustion chamber, with no loss of combustion efficiency. The soot emissions are extremely low regardless of the injection pressure $[4,20]$ or EGR rate. At a high EGR rate could greatly facilitate the use of eco-friendly DME-fueled CI engines.

Author Contributions: I.Y.: Concept, Experiments, Investigation, J.J.: original draft writing, review \& editing. All authors have read and agreed to the published version of the manuscript.

Funding: This research was supported by Basic Science Research Program through the National Research Foundation of Korea(NRF) funded by the Ministry of Education(2021R1I1A305197611).

Institutional Review Board Statement: Not applicable. 
Informed Consent Statement: Not applicable.

Data Availability Statement: Not applicable.

Conflicts of Interest: The authors declare no conflict of interest.

$\begin{array}{ll}\text { Abbreviations } \\ \text { ABDC } & \text { after bottom-dead-center } \\ \text { BBDC } & \text { before bottom-dead-center } \\ \text { ATDC } & \text { after top-dead-center } \\ \text { BTDC } & \text { before top-dead-center } \\ \text { CAD } & \text { crank angle degree } \\ \text { DME } & \text { dimethyl ether } \\ \text { EGR } & \text { exhaust gas recirculation } \\ \text { HRR } & \text { heat release rate } \\ \text { ISFC } & \text { indicated specific fuel consumption } \\ \text { ITE } & \text { indicated thermal efficiency } \\ P_{\text {inj }} & \text { injection pressure } \\ \text { TDC } & \text { top-dead center } \\ \tau_{\text {inj }} & \text { injection timing } \\ \text { ULSD } & \text { ultra-low-sulfur diesel }\end{array}$

\section{References}

1. Wróblewski, P.; Koszalka, G. An Experimental Study on Frictional Losses of Coated Piston Rings with Symmetric and Asymmetric Geometry. SAE Int. J. Eng. 2021, 14, 853-866. [CrossRef]

2. Wróblewski, P. Technology for Obtaining Asymmetries of Stereometric Shapes of the Sealing Rings Sliding Surfaces for Selected Anti-Wear Coatings; No. 2020-01-2229; SAE International: Warrendale, PA, USA, 2020.

3. Shi, L.; Ji, C.; Wang, S.; Cong, X.; Su, T.; Shi, C. Impacts of dimethyl ether enrichment and various injection strategies on combustion and emissions of direct injection gasoline engines in the lean-burn condition. Fuel 2019, 254, 115636. [CrossRef]

4. Anubhav, N.K.; Saluja, R.K. Optimization of Fuel Injection Strategies for Sustainability of DME in Combustion Engine. In Greener and Scalable E-Fuels for Decarbonization of Transport; Agarwal, A.K., Valera, H., Eds.; Springer: Singapore, 2022; pp. $293-314$.

5. Gharehghani, A.; Kakoee, A.; Andwari, A.M.; Megaritis, T.; Pesyridis, A. Numerical Investigation of an RCCI Engine Fueled with Natural Gas/Dimethyl-Ether in Various Injection Strategies. Energies 2021, 14, 1638. [CrossRef]

6. Mehra, S.; Agarwal, A.K. Prospects and Challenges of DME Fueled Low-Temperature Combustion Engine Technology. In Greener and Scalable E-Fuels for Decarbonization of Transport; Agarwal, A.K., Valera, H., Eds.; Springer: Singapore, 2022 ; pp. $261-291$.

7. Jeon, J.; Kwon, S.I.; Park, Y.H.; Oh, Y.; Park, S. Visualizations of combustion and fuel/air mixture formation processes in a single cylinder engine fueled with DME. Appl. Energy 2014, 113, 294-301. [CrossRef]

8. Youn, I.M.; Park, S.H.; Roh, H.G.; Lee, C.S. Investigation on the fuel spray and emission reduction characteristics for dimethyl ether (DME) fueled multi-cylinder diesel engine with common-rail injection system. Fuel Process. Technol. 2011, 92, $1280-1287$. [CrossRef]

9. Fabiś, P.; Flekiewicz, B. Influence of LPG and DME Composition on Spark Ignition Engine Performance. Energies 2021, 14, 5583. [CrossRef]

10. Li, X.; He, B.-Q.; Zhao, H. Study on micro-flame ignited (MFI) hybrid combustion characteristics of a dual-fuel optical engine at different lambdas. Fuel 2021, 290, 119796. [CrossRef]

11. Jeon, J.; Park, Y.H.; Kwon, S.I.; Park, S. Effect of Pilot Injection Timings on the Combustion Temperature Distribution in a Single-Cylinder CI Engine Fueled with DME and ULSD. Oil Gas Sci. Technol.-Rev. D'ifp Energ. Nouv. 2016, 71, 15. [CrossRef]

12. Pham, V.C.; Rho, B.-S.; Kim, J.-S.; Lee, W.-J.; Choi, J.-H. Effects of Various Fuels on Combustion and Emission Characteristics of a Four-Stroke Dual-Fuel Marine Engine. J. Mar. Sci. Eng. 2021, 9, 1072. [CrossRef]

13. Kamei, W.; Sahoo, N.; Prasad, V.V.D.N. Dimethyl Ether and Liquefied Petroleum Gas Co-Fumigation and Oxidation Catalyst Exhaust Aftertreatment: A Synergy for Improvement of Thermal Efficiency and Emissions in a Dual-Fuel Engine. J. Energy Resour. Technol. 2021, 143, 11. [CrossRef]

14. Ezoji, H.; Shafaghat, R.; Jahanian, O. Numerical simulation of dimethyl ether/natural gas blend fuel HCCI combustion to investigate the effects of operational parameters on combustion and emissions. J. Therm. Anal. Calorim. 2019, 135, 1775-1785. [CrossRef]

15. Lokachari, N.; Wagnon, S.W.; Kukkadapu, G.; Pitz, W.J.; Curran, H.J. An experimental and kinetic modeling study of cyclopentane and dimethyl ether blends. Combust Flame 2021, 225, 255-271. [CrossRef]

16. Algayyim, S.J.M.; Wandel, A.P. Macroscopic and microscopic characteristics of biofuel spray (biodiesel and alcohols) in CI engines: A review. Fuel 2021, 292, 120303. [CrossRef] 
17. Sivalingam, S.; Palanisamy, P.; Baluchamy, A. Experimental investigation on Jatropha oil Methyl Ester fuelled CI engine using high EGR. Mater. Today Proc. 2021, 39, 274-278. [CrossRef]

18. Shao, Z.; Wang, J.; Han, Y.; Xu, L.; Tian, J. The synergistic effect of fuel aromatic components refinement and ignition timing on GDI engine performance and emissions. Fuel 2021, 298, 120800. [CrossRef]

19. Park, S.H.; Lee, C.S. Applicability of dimethyl ether (DME) in a compression ignition engine as an alternative fuel. Energy Convers. Manag. 2014, 86, 848-863. [CrossRef]

20. Park, S.H.; Lee, C.S. Combustion performance and emission reduction characteristics of automotive DME engine system. Prog. Energy Combust. Sci. 2013, 39, 147-168. [CrossRef]

21. Putrasari, Y.; Lim, O. Dimethyl Ether as the Next Generation Fuel to Control Nitrogen Oxides and Particulate Matter Emissions from Internal Combustion Engines: A Review. ACS Omega 2022, 7, 32-37. [CrossRef]

22. Teng, H.; McCandless, J.C.; Schneyer, J.B. Compression Ignition Delay (Physical + Chemical) of Dimethyl Ether-An Alternative Fuel for Compression-Ignition Engines; SAE International: Warrendale, PA, USA, 2003.

23. Thomas, G.; Feng, B.; Veeraragavan, A.; Cleary, M.J.; Drinnan, N. Emissions from DME combustion in diesel engines and their implications on meeting future emission norms: A review. Fuel Process. Technol. 2014, 119, 286-304. [CrossRef]

24. Kapus, P.; Ofner, H. Development of Fuel Injection Equipment and Combustion System for DI Diesels Operated on Dimethyl Ether; SAE International: Warrendale, PA, USA, 1995.

25. Suh, H.K.; Park, S.H.; Kim, H.J.; Lee, C.S. Influence of ambient flow conditions on the droplet atomization characteristics of dimethyl ether (DME). Fuel 2009, 88, 1070-1077. [CrossRef]

26. Sivebaek, I.M.; Sorenson, S.C.; Jakobsen, J. Dimethyl Ether (DME)—Assessment of Viscosity Using the New Volatile Fuel Viscometer (VFVM); SAE International: Warrendale, PA, USA, 2001.

27. Teng, H.; McCandless, J.C.; Schneyer, J.B. Viscosity and Lubricity of (Liquid) Dimethyl Ether-An Alternative Fuel for CompressionIgnition Engines; SAE International: Warrendale, PA, USA, 2002.

28. Sorenson, S.C.; Glensvig, M.; Abata, D.L. Dimethyl Ether in Diesel Fuel Injection Systems; SAE International: Warrendale, PA, USA, 1998.

29. Sezer, İ. Thermodynamic, performance and emission investigation of a diesel engine running on dimethyl ether and diethyl ether. Int. J. Therm. Sci. 2011, 50, 1594-1603. [CrossRef]

30. Yu, J.; Bae, C. Dimethyl ether (DME) spray characteristics in a common-rail fuel injection system. Proc. Inst. Mech. Eng. Part D J. Automob. Eng. 2003, 217, 1135-1144. [CrossRef]

31. Kim, M.Y.; Yoon, S.H.; Ryu, B.W.; Lee, C.S. Combustion and emission characteristics of DME as an alternative fuel for compression ignition engines with a high pressure injection system. Fuel 2008, 87, 2779-2786. [CrossRef]

32. Teng, H.; McCandless, J.C.; Schneyer, J.B. Thermochemical Characteristics of Dimethyl Ether-An Alternative Fuel for CompressionIgnition Engines; SAE International: Warrendale, PA, USA, 2001.

33. Park, S.W. Numerical Study on Optimal Operating Conditions of Homogeneous Charge Compression Ignition Engines Fueled with Dimethyl Ether and n-Heptane. Energy Fuels 2009, 23, 3909-3918. [CrossRef] 